\title{
NOTE
}

\section{Do sandy beaches accumulate nitrogen?}

\author{
Anton McLachlan \& Lesley McGwynne
}

Zoology Department, University of Port Elizabeth, PO Box 1600, Port Elizabeth 6000, South Africa

\begin{abstract}
A moderate-energy sandy beach receiving a high natural organic load of stranded wrack was studied over $1 \mathrm{yr}$. Nitrogen input to the beach was calculated from wrack nitrogen content, an average standing stock of $72 \mathrm{~kg} \mathrm{~m}^{-1}$ wet wrack and a turnover time of $9 \mathrm{~d}$, estimated from litter bag ( $2 \mathrm{~mm}$ mesh) experiments. Nitrogen in the beach was measured as bacterial biomass (mean $105 \mathrm{~g} \mathrm{~N} \mathrm{~m}^{-1}$ ), meiofauna biomass (mean $0.1 \mathrm{~g} \mathrm{~N} \mathrm{~m}^{-1}$ ) and interstitial water inorganic nitrogen (mean $83 \mathrm{~g} \mathrm{~N} \mathrm{~m}^{-1}$ ). Wrack nitrogen input was in excess of $14 \mathrm{~kg} \mathrm{~N} \mathrm{~m}^{-1} \mathrm{yr}^{-1}$. Despite receiving a high nitrogen load, this beach did not exhibit any net accumulation of nitrogen over the year.
\end{abstract}

Marine sandy beaches receive a variety of organic materials from the sea: macrophyte wrack, dead animals and dissolved and particulate organics flushed through the sand during the process of swash-water filtration (Riedl 1971, McLachlan 1983). Incorporated with this is nitrogen which is released when the material is consumed or mineralised on the beach. The nitrogen released can either be returned to the sea, trapped in the beach by incorporation into microbial or faunal biomass or in inorganic form in the groundwater (Eagle 1983), or lost by denitrification.

Coastal areas are generally regarded as nitrogen sinks (Nixon 1981). Koop et al. (1982) and Koop \& Lucas (1983), studying kelp wrack breakdown on an artificial sandy beach over $8 \mathrm{~d}$, found most of the nitrogen to be converted to bacterial biomass and only $1.5 \%$ to return to the sea. Hennig et al. (1983) examined nutrient cycling in small laboratory sand columns over $90 \mathrm{~min}$ periods and found the sand to accumulate nitrogen, concluding that beaches are nitrogen sinks. It seems intuitively obvious, however, that all nitrogen supplied to a beach in organic or inorganic form must ultimately return to the sea (Oliff et al. 1970, Pugh 1976, Eagle 1983) or the beach would, on geological time scales, show signs of such accumulations. The present study represents an attempt to address this apparent paradox.

We selected a beach receiving a relatively high natural organic input, measured this input in terms of nitrogen at the beginning and end of a $1 \mathrm{yr}$ period and recorded possible signs of accumulation of nitrogen in the beach fauna or groundwater. The outcome is discussed in the framework of a variety of beach types.

Methods. The monitoring program was conducted on a stable, moderate-energy shore near Port Elizabeth, which consists of a rocky platform at the mid-tide level with a sandy beach overlying it, giving way to dunes just above the drift line. This beach has an average slope of $1 / 11$, a width of $30 \mathrm{~m}$ and a mean particle size of $300 \mu \mathrm{m}$. Mean monthly sea temperature range is 15 to $21^{\circ} \mathrm{C}$ and maximum spring tidal range $2.1 \mathrm{~m}$. The beach receives a regular input of algae torn loose from the adjacent rocky coast.

Field work stretched from March 1984 to March 1985. For parameters other than wrack input, sampling was conducted at the beginning and end of the year period. Wrack was collected every 3 to 4 wk. Four equidistant sites up the beach were marked for sampling, from Site 1, the mid-water of spring tides (MWS), to Site 4, the high water of springs (HWS). For meiofauna, sampling extended vertically in $15 \mathrm{~cm}$ intervals into the sand as far as the low tide water table. Four replicate cores $\left(15 \mathrm{~cm}\right.$ long $\times 10 \mathrm{~cm}^{2}$ were taken of which 2 were pooled. The fauna were narcotised with $7 \% \mathrm{MgCl}_{2}$ and fixed in $10 \%$ formalin. Duplicate sand cores of $10 \mathrm{~cm}^{3}$ for bacterial counts were taken at 10 to $20 \mathrm{~cm}$ vertical intervals at each site using a modified syringe and stored in $2 \%$ filtered formalin. Groundwater was collected at the water table. To collect wrack, a metal hoop covering $0.1 \mathrm{~m}^{2}$ was placed on the sand surface every $1 \mathrm{~m}$ along a transect covering the length of the beach. All algae within the hoop were weighed using a Pesola spring balance.

Subsamples of $100 \mathrm{~cm}^{2}$ were removed from the meiofauna cores, extracted by 4 decants through a $45 \mu \mathrm{m}$ screen, stained in rose bengal and counted to major taxa. Counts were corrected for $90 \%$ extraction 
efficiency (McLachlan 1978). For bacterial counts duplicate $0.5 \mathrm{~g}$ samples of wet sand were sonicated 3 times each for $5 \mathrm{~min}$ in $5 \mathrm{ml}$ filtered $2 \%$ formalin at a sonication frequency of $25 \mathrm{kHz}$. Of the $15 \mathrm{ml}$ supernatant $0.5 \mathrm{ml}$ was filtered through a $0.2 \mu \mathrm{m}$ Nuclepore polycarbonate filter and stained with DAPI (Coleman 1980). Bacteria were then counted using an epifluorescence microscope. Porosity of the sand was measured as the volume of water needed to saturate $100 \mathrm{~cm}^{3}$ oven-dried sand. Groundwater samples were analysed for $\mathrm{NH}_{3}-\mathrm{N}, \mathrm{NO}_{2}-\mathrm{N}, \mathrm{NO}_{3}-\mathrm{N}$ and total nitrogen on a Technicon Autoanalyser II.

At the beginning and end of the program, wrack was separated into component species and the total wet mass of each obtained. Subsamples were then used to estimate percent moisture by drying at $70^{\circ} \mathrm{C}$ and nitrogen by the microkjeldahl method (Holme \& McIntyre 1971).

A litter bag experiment estimated the breakdown rates of algal wrack exposed to desiccating elements on the beach. One hundred $50 \mathrm{~g}$ samples of freshly collected algae from the nearby rocky shore were placed in nylon bags of $2 \mathrm{~mm}$ mesh and strewn over the beach. Bags were retrieved at daily intervals and weighed to obtain wet mass. The experiment was carried out in early spring using the more abundant red alga, Hypnea rosea.

Results. Wrack was distributed over the whole beach face but often concentrated towards the upper shore. The total volume of the triangular wedge of sand between the rock base and the drift line marker was $27.5 \mathrm{~m}^{3}$ per running metre. Based on a mean porosity of $45 \%$ by volume this reduces to $12.4 \mathrm{~m}^{3}$ pore space, mostly filled with interstitial water, and $14.1 \mathrm{~m}^{3}$ sand grains. The volume of interstitial water held at low tide was estimated to be $9.4 \mathrm{~m}^{3}$, allowing for ca $3 \mathrm{~m}^{3}$ air space above the water table.

The water table at the time of sampling was close to the surface and showed evidence of groundwater seepage as salinities from 0 to $34 \%$ were regularly recorded during wrack collections, particularly at upper tide levels. At initial and final sampling (March $1984,1985)$ all salinities were above $16 \%$. Reduced layers were noted at the 2 middle sampling sites, on both occasions within $10 \mathrm{~cm}$ of the sand surface.

Bacterial densities were fairly uniform across the beach and there were no significant differences between sampling sites or depths on either occasion (2way ANOVA, $\mathrm{p}<0.05$ ), although densities tended to be higher at lower shore levels. Mean numbers per $g$ wet sand were 2 orders of magnitide lower during March $1985\left(3.62 \times 10^{6}\right)$ than March $1984\left(2.4 \times 10^{8}\right)$ probably due to different wrack input immediately preceding sampling.

There were large differences in groundwater nu- trient levels between sites and dates. The residence time of water in the beach is 12 to $24 \mathrm{~h}$ (McLachlan 1979, 1982), sufficient for the oxidation of much ammonium to nitrate. The concentrations of all 3 oxidation states of nitrogen were significantly higher during 1985 than 1984 (2-way ANOVA, $p<0.001)$. Due to analytical problems, total nitrogen analysis was only done at the end of the study period. At this time total nitrogen values were 2.5 to 4.4 times the total inorganic nitrogen values, suggesting that 59 to $77 \%$ (mean $67 \%$ ) of the nitrogen in the interstitial water was in organic form. Since this includes organisms such as bacteria, Protozoa and meiofauna, approximately $50 \%$ of the non-living nitrogen in the interstitial water may have been in inorganic form during the time of final sampling.

The standing stock of wrack recorded along the transect over the year is summarised in Table 1 . The mean quantity of wet wrack on the beach was $72 \mathrm{~kg}$

Table 1. Standing stocks of algal wrack recorded over 12 mo

\begin{tabular}{|cclc|}
\hline Date & $\begin{array}{c}\text { Total wet mass } \\
\left(\mathrm{kg} \mathrm{m}^{-1}\right)\end{array}$ & Tide & $\begin{array}{c}\text { Transect length } \\
(\mathrm{m})\end{array}$ \\
\hline 23 Feb 1984 & 154.1 & Neaps & 21 \\
30 Apr & 14.9 & Springs & 20 \\
30 May & 27.2 & Springs & 20 \\
3 Jul & 0.6 & Neaps & 25 \\
27 Jul & 2.9 & Springs & 24 \\
7 Sep & 5.4 & Neaps & 25 \\
24 Sep & 76.5 & Springs & 20 \\
31 Oct & 48.8 & Neaps & 20 \\
29 Nov & 11.2 & Neaps & 18 \\
9 Jan 1985 & 508.3 & Springs & 19 \\
12 Feb & 10.9 & Neaps & 22 \\
5 Mar & 2.9 & Springs & 25 \\
Mean & 72.0 & & 21.6 \\
\hline
\end{tabular}

$\mathrm{m}^{-1}$ spread over a lane averaging $21.6 \mathrm{~m}$ up the beach. This varied drastically between virtual absence of wrack on 3 July to dense accumulations on 9 January.

Fifteen species of algae were recorded, mostly reds including 3 coralline species. Hypnea rosea and Plocamium corallorhiza formed $78.8 \%$ of total wrack mass. No measure of variation in wrack composition during the year was taken. The nitrogen content of beached algae ranged from 0.67 to $3.70 \%$ dry mass, with corallines giving the lowest figures. The 2 most abundant species averaged $2.45 \%$ nitrogen. On average, dry mass made up $36.6 \%$ of wet mass for all species on the beach but only $13.6 \%$ of wet mass of freshly collected algae, indicating that desiccation occurred rapidly on the beach.

The litter bag experiment was performed using Hypnea rosea and 15 bags were recovered within $10 \mathrm{~d}$ 


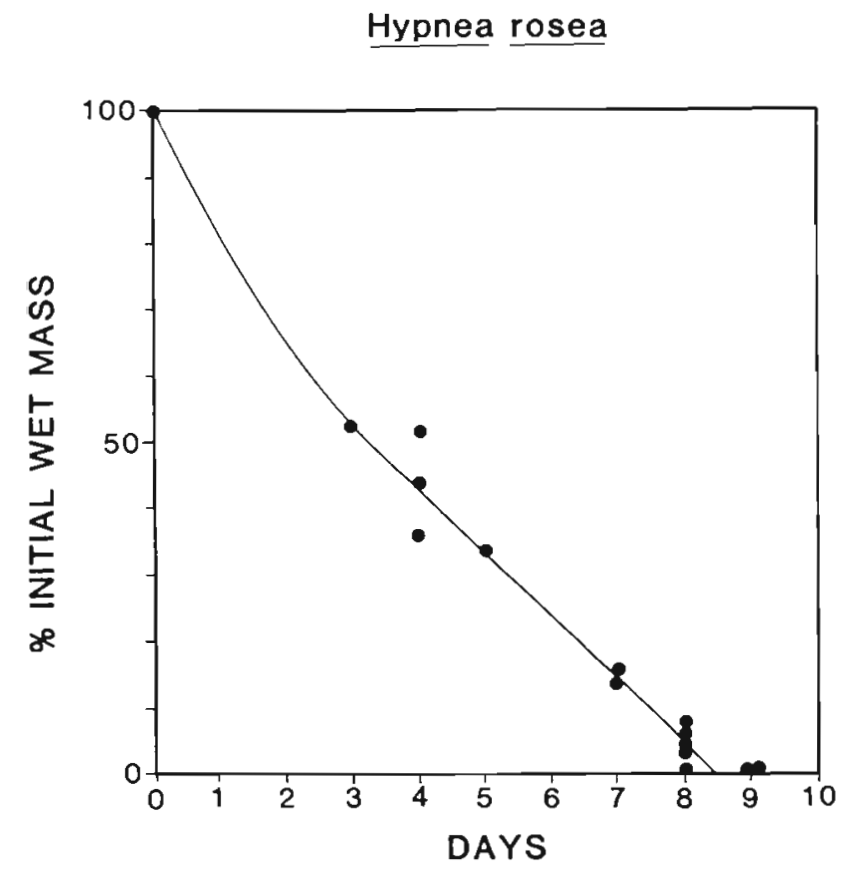

Fig. 1. Loss of wet mass in litter bags. Line fitted by eye

of the start of the experiment. Results are plotted in Fig. 1. Mass loss in the bags was nearly linear and reached $50 \%$ in $3 \mathrm{~d}$. After Day 8 all bags collected were empty. Breakdown of algae on this beach to fragments $<2 \mathrm{~mm}$ thus occurred within $9 \mathrm{~d}$ in early spring. It would probably be more rapid during summer.

Based on a mean mass of $72 \mathrm{~kg}$ wet wrack $\mathrm{m}^{-1}$ on the beach and a turnover time of $9 \mathrm{~d}$, total wrack input is estimated to be $2920 \mathrm{~kg} \mathrm{~m}^{-1} \mathrm{yr}^{-1}$. From this information and dry mass and nitrogen content measured for each component species of the wrack (mean $1.94 \pm 0.91 \%$ ) it is possible to estimate the nitrogen input from this source. Possible long-term accumulation of $\mathrm{N}$ was monitored in meiofaunal and bacterial biomass and in inorganic nutrients in the groundwater. Interstitial organic nitrogen was not measured. Interstitial water nitrogen was estimated by multiplying total inorganic nitrogen values by water volumes below each sampling level to give total nitrogen in a water volume of $9.4 \mathrm{~m}^{3}$. Bacterial nitrogen was calculated by multiplying bacterial numbers obtained for the whole sand wedge by a mean dry biomass of $1.5 \times 10^{-13} \mathrm{~g}$ per individual (Koop \& Griffiths 1982) and a nitrogen content of $10 \%$ (Luria 1960, Fenchel \& Blackburn 1979, Koop \& Lucas 1983). Similarly, meiofaunal numbers were summed (assuming that all meiofauna occurred only in the sampled layers) and multiplied by individual biomass figures from McLachlan (1977) and Widbom (1984) and a mean nitrogen content of $10 \%$.

The total wrack nitrogen input was in excess of $14 \mathrm{~kg}$ $\mathrm{m}^{-1} \mathrm{yr}^{-1}$ (Table 2) and was made up $48 \%$ by Hypnea rosea, $28 \%$ by Plocamium corallorhiza, $9 \%$ by Amphiroa ephedrea and $5 \%$ by Laurencia natalensis. These species dominate the adjacent reefs throughout the year. The volumes of groundwater associated with each sampling level per running metre of beach were calculated to be $480 \mathrm{l}$ at Site 1, $1980 \mathrm{l}$ at Site 2, $3750 \mathrm{l}$ at Site 3 and $3190 \mathrm{l}$ at Site 4 . Based on these figures and inorganic nitrogen concentrations, groundwater nitrogen in the final sample was $127 \mathrm{~g} \mathrm{~m}^{-1} \mathrm{yr}^{-1}$, higher than the initial measurement. This was due to very high levels associated with increased anoxic conditions immediately prior to sampling, probably following a heavy loading of the intertidal with organic material. Bacterial nitrogen was markedly lower at the final sampling, the result of a decrease in bacterial densities by 2 orders of magnitude. The decreased bacterial numbers may have been a direct consequence of the increased levels of ammonia and other reduced compounds associated with anoxic conditions prevailing at the time. Thus nutrient levels and microbial biomass may show inverse fluctuations thereby tending to buffer changes in nitrogen held in the beach as wrack input changes over short periods. Meiofaunal nitrogen showed a slight decrease $\{0.02 \mathrm{~g})$ between the 2 samples.

The amount of $\mathrm{N}$ present in the sand wedge, when averaged between the 2 sampling times, was calculated at $188 \mathrm{~g} \mathrm{~m}^{-1}$, representing $1.3 \%$ of the total amount of wrack nitrogen processed by the beach in a year. However, this amount does not include interstitial organic nitrogen as it was not possible to separate this from bacterial and other biomass. If organic nitro-

Table 2. Changes in the 3 selected beach components for the study beach measured at the beginning and end of a year. All values in $\mathrm{gN} \mathrm{m}^{-1}$

\begin{tabular}{|lcc|}
\hline \multicolumn{1}{|c}{ Component } & Value & Total \\
\hline Wrack N input & & 14338 \\
Initial standing stocks & & \\
Groundwater & 19 & \\
Bacteria & 207 & \\
Meiofauna & 0.1 & \\
Final standing stocks & & \\
Groundwater & 146 & \\
Bacteria & 3 & \\
Meiofauna & 0.1 & \\
Net change & & \\
Groundwater & +127 & \\
Bacteria & -204 & \\
Meiofauna & Nil & \\
Cycled to nearshore? & & 1445 \\
\hline
\end{tabular}


gen is approximately as abundant as inorganic nitrogen this would raise the pool to $267 \mathrm{~g} \mathrm{~N}$ in the beach. Considering the small proportion of the total nitrogen input present in the groundwater at one time and the absence of notable accumulations by measured components of the sand wedge, it is evident that this beach does not retain nitrogen although its nitrogen content may show short-term fluctuations in response to variable wrack input and other factors.

Discussion. This study was aimed at clarifying whether sandy beaches accumulate or recycle N. Considering the gross quantity of $N$ entering the beach through the decomposition of algal wrack, the question was tackled by monitoring 3 potential avenues of $N$ storage over the span of a year. The amount of $N$ measured in the study beach both initially and finally is considerably less than the total amount being processed through the beach over a year. By focussing on 3 specific parameters which would inevitably reflect nutrient accumulation, were it to occur, the question has been resolved relatively simply.

Discharge of groundwater into the shallow subtidal or intertidal is a feature of most sandy shores (Johannes 1980). The study area is no exception as evidenced by the low interstitial salinities. Average groundwater flows in this area are about $1000 \mathrm{~lm}^{-1} \mathrm{~d}^{-1}$ (McLachlan \& Illenberger 1986), which, at a nitrogen level of $2 \mathrm{mg}$ $\mathrm{N}^{-1}$, would supply an additional $730 \mathrm{~g} \mathrm{~N} \mathrm{~m}^{-1} \mathrm{yr}^{-1}$. This groundwater would also flush out the resident interstitial water.

In addition to the flushing by groundwater, the beach is flushed twice daily during the high tides. This swash filtration through the beach face has been well described for sandy beaches (Riedl \& Machan 1972 , McLachlan 1979, 1982). Exposed beaches in this area generally filter $10^{4} 1$ seawater daily per lengthwise metre with a residence time of ca 24 h (McLachlan 1979). Because of its sheltered nature this beach would probably only filter half this amount or $5000 \mathrm{l} \mathrm{m}^{-1} \mathrm{~d}^{-1}$, 5 times the daily groundwater input. This flushed water has a residence time in the order of 12 to $24 \mathrm{~h}$.

Nitrogen fixation is not likely to be important (Keeney 1973). Sorensen (1978) and Kaspar (1983) concluded that denitrification is restricted to the upper centimetres of sediment, i.e. the aerobic/anaerobic interface, and Koop \& Lucas (1983) recorded a loss of only $2.3 \%$ of kelp wrack nitrogen supplied to a beach. most of this presumably going to the atmosphere. It appears unlikely that dentrification could remove more than 5 to $10 \%$ of the nitrogen input to our study beach.

Through the processes of groundwater and diurnal tidal flushing the accumulation of $N$, in its many and varied forms and from its numerous sources, is unlikely. Calculated mean turnover time based on
$180 \mathrm{~g} \mathrm{~N} \mathrm{~m}^{-1}$ in the beach and $15000 \mathrm{~g} \mathrm{~m}^{-1}$ input in 365 $\mathrm{d}$ is 4.4 days (or $6.3 \mathrm{~d}$ if the pool is $260 \mathrm{~g} \mathrm{~N} \mathrm{~m}^{-1}$ ). Ultimately, this nitrogen must be returned to the sea while the beach remains reasonably close to some equilibrium nitrogen level. Boucher \& Chamroux (1976) found no organic nitrogen accumulation in sand columns maintained for 16 mo on amino acids although bacterial biomass did increase (Chamroux et al. 1977).

The equilibrium level of nutrients for any particular beach is determined by a complex of chemical, physical and biological factors (Pugh 1983), but primarily by the organic input it receives (Oliff et al. 1970). The study beach, receiving a high organic loading and having sand with relatively low permeability, has high equilibrium levels of nutrients and reducing conditions deeper in the sediment. The reduced form, ammonia, thus dominated inorganic nitrogen in the interstitial water. The discharging groundwater, in contrast, is higher in nitrate (McLachlan \& Illenberger 1986).

If the study beach does not accumulate nitrogen, to what extent does this conclusion apply to other beaches? We believe that this is not universally applicable. Beaches may be seen in 3 categories: eroding, equilibrium and prograding (i.e. advancing). Eroding beaches by their very nature, are unlikely to be nitrogen sinks. Stable beaches, such as the one we have studied, we suggest are not nitrogen sinks. Groundwater and wave flushing combine to keep them in an equilibrium state determined by a variety of factors, particularly organic input. However, prograding beaches probably are nitrogen sinks, except where groundwater flow is high enough to flush nutrients from the system faster than the sand accumulates them. For example, the beach at Cervantes, Western Australia, is prograding at a rate of $5 \mathrm{~m} \mathrm{yr}^{-1}$ (Hesp 1984). Excavating in the dunes $200 \mathrm{~m}$ from the beach, the first author recovered partially decomposed algae, remnants from the driftline of $40 \mathrm{yr}$ earlier. Clearly this beach was a nitrogen sink.

The world's shorelines generally are in a state of erosion (Bird 1983) and prograding shores are a rarity. With the exception of prograding beaches therefore, we suggest that ocean beaches generally are not nitrogen sinks but cycle their nitrogen inputs rapidly back to the sea with a small possible loss to the atmosphere by denitrification. Chemical equilibria in the beach are maintained in response to organic loading, hydrodynamic forces, sand particle size and biological processes. While these equilibria may shift with tides, storms, seasons and changes in organic input, in the natural situation no long-term net accumulation is likely to occur. Because the beach and its immediate sublittoral is the zone of discharge of groundwater 
high in nitrogen, it may be seen as a source of recycled nitrogen to coastal waters.

Acknowledgements. We thank Bruce Tomalin, Vanessa Talbot, Wendy du Preez and Andy Cockcroft for assistance, Magda Maree for preparing the figures and Mrs. A. J. Gerber for typing the manuscript. Funding was generously provided by the CSIR, University of Port Elizabeth and the Department of Environmental Affairs

\section{LITERATURE CITED}

Bird, E. C. F. (1983). Factors influencing beach erosion and accretion. A global review, In: McLachlan, A., Erasmus, T. (ed.) Sandy beaches as ecosystems. Junk, The Hague p. 709-717

Boucher, G., Chamroux, S. (1976). Bacteria and meiofauna in an experimental sand ecosystem. I. Material and preliminary results. J. exp. mar. Biol. Ecol. 24: 237-249

Chamroux, S., Boucher, G., Bodin, P. (1977). Étude experimentale d'un ecosystem sableux. II. Evolution des populations de bacteries et de meiofaune. Helgoländer wiss. Meeresunters. 30: 163-177

Coleman, A. W. (1980). Enhanced detection of bacteria in natural environments by fluorochrome staining of DNA. Limnol. Oceanogr. 25: 948-951

Eagle, G. A. (1983). The chemistry of sandy beach ecosystems - a review. In: McLachlan, A., Erasmus, T. (ed.) Sandy beaches as ecosystems. Junk, The Hague, p. 203-224

Fenchel, T., Blackburn, T. H. (1979). Bacteria and mineral cycling. Academic Press, London

Hennig, H. F. K. O., Fricke, A. H., Martin, C. T. (1983). The effect of meiofauna and bacteria on nutrient cycles in sandy beaches. In: McLachlan, A., Erasmus, T. (ed.) Sandy beaches as ecosystems. Junk, The Hague, p. 235-248

Hesp, P. (1984). The formation of sand beaches, ridges and foredunes. Search 15: 289-291

Holme, N. A., McIntyre, A. D. (1971). Methods for the study of marine benthos. IBP handbook no 16. Blackwell, Oxford

Johannes, R. E. (1980). The ecological significance of the submarine discharge of groundwater. Mar. Ecol. Prog Ser. 3: 365-373

Kaspar, H. F. (1983). Denitrification, nitrate reduction to ammonium, and inorganic nitrogen pools in intertidal sediments. Mar. Biol. 74: 133-139

Keeney, D. R. (1973). The nitrogen cycle in sediment-water systems. J. environ. Qual. 2: 15-29

Koop, K., Griffiths, C. L. (1982). The relative significance of bacteria, meio- and macrofauna on an exposed sandy beach. Mar. Biol. 66: 295-300

Koop, K., Newell, R. C., Lucas, M. I. (1982). Microbial regen- eration of nutrients from the decomposition of macrophyte debris on the shore. Mar. Ecol. Prog. Ser. 9: 91-96

Koop, K., Lucas, M. I. (1983). Carbon flow and nutrient regeneration from the decomposition of macrophyte debris in a sandy beach microcosm. In: McLachlan, A., Erasmus, T. (ed.) Sandy beaches as ecosystems. Junk, The Hague, p. $249-262$

Luria, S. E. (1960). The bacterial protoplasm: composition and organisation. In: Gunsalus, I. C., Stanier, R. Y. (ed.) The Bacteria, Vol. I. Academic Press, New York pp. 1-34

McLachlan, A. (1977). Composition, distribution, abundance and biomass of the macrofauna and meiofauna of four sandy beaches. Zool. Afr. 12: 279-306

McLachlan, A. (1978). A quantitative analysis of the meiofauna and the chemistry of the redox potential discontinuity zone in a sheltered sandy beach. Estuar. coast. mar. Sci. 7: 275-290

McLachlan, A. (1979). Volumes of sea water filtered through eastern Cape sandy beaches. S. Afr. J. Sci. 75: 75-79

McLachlan, A. (1982). A model for the estimation of water filtration and nutrient regeneration by exposed sandy beaches. Mar. environ. Res. 6: 37-47

McLachlan, A. (1983). Sandy beach ecology - a review. In: McLachlan, A., Erasmus, T. (ed.) Sandy beaches as ecosystems. Junk, The Hague, p. 321-380

McLachlan, A., Illenberger, W. (1986). Significance of groundwater nitrogen input to a beach/surf zone ecosystem. Stygologia (in press)

Nixon, S. W. (1981). Remineralisation and nutrient cycling in coastal marine ecosystems. In: Nielson, B. J., Cronin, L. E. (ed.) Estuaries and nutrients. Humana Press, Clifton, New Jersey, p. 111-138

Oliff, W. D., Gardner, B., Turner, W. D., Sharp, J. B. (1970). The chemistry of the interstitial waters as a measure of conditions in a sandy beach. Water Res. $4: 179-188$

Pugh, K. B. (1976). An annual cycle, at constant temperature, in a model sandy beach. I. Nutrient chemistry. J. exp. mar. Biol. Ecol, 22: 179-192

Pugh, K. B. (1983). Nutrient cycling in sandy beaches. In McLachlan, A., Erasmus, T. (ed.) Sandy beaches as ecosystems. Junk, The Hague, p. 225-233

Riedl, R. (1971). How much seawater passes through sandy beaches? Int. Revue ges. Hydrobiol. 56: 923-946

Riedl, R., Machan, R. (1972). Hydrodynamic patterns in lotic intertidal sands and their bioclimatological implications. Mar. Biol. 13: 179-209

Sorensen, J. (1978). Capacity for denitrification and reduction of nitrate to ammonia in a coastal marine sediment. Appl. environ. Microbiol. 35: 301-305

Widbom, B. (1984). Determination of average individual dry weights and ash-free dry weights in different sieve fractions of marine meiofauna. Mar. Biol. 84: 101-108

Accepted for printing on September 5, 1986 